\title{
HUBUNGAN KONTROL DIRI DENGAN PERILAKU MEROKOK KALANGAN REMAJA DI SMKN 1 BITUNG
}

\author{
${ }^{1}$ Gretty C. Runtukahu \\ ${ }^{2}$ Jehosua Sinolungan \\ ${ }^{2}$ Henry Opod
}

\author{
${ }^{1}$ Kandidat Skripsi Fakultas Kedokteran Universitas Sam Ratulangi Manado \\ ${ }^{2}$ Staf Bagian Psikologi Fakultas Kedokteran Universitas Sam Ratulangi Manado \\ Email:gruntukahu11_031@yahoo.com
}

\begin{abstract}
Low self-control makes teenagers are not able to organize and direct the behavior that appears uncontrolled actions such as smoking. Changes in the state of teenages who should learn to be more interested in smoking, associated with high-low self-control. This study aimed to determine the relationship between self-control and smoking behavior among adolescents. The research method using cross sectional design and quantitative analytic. The study involved 176 active students of the school as a sample, smoking and non smoking, male or female, and is willing to participate. Collecting data through questionnaires. Data analysis technique using the Spearman rank correlation test. The results show the value of $r=-0,756$ with $\mathrm{p}=0,000(\mathrm{p}<0,05)$, meaning that the higher self-control teenagers applied, the lower the level of smoking behavior. Analysis of the 44 smokers from the total sample of 176 respondents, the value of $r=-0,766$ with $p=0,000(p<0.05)$, meaning that the lower selfcontrol teenagers applied, the higher the level of smoking behavior. Thus the hypothesis $\mathrm{H} 1$ is accepted, that there is a significant negative relationship between self-control and smoking behavior .
\end{abstract}

Keywords : self-control, smoking behavior, adolescent

\begin{abstract}
Abstrak: Kontrol diri yang rendah membuat remaja tidak mampu mengatur dan mengarahkan perilakunya sehingga muncul tindakan tidak terkontrol seperti perilaku merokok. Perubahan keadaan dari remaja yang seharusnya belajar menjadi remaja yang lebih tertarik merokok berkaitan dengan tinggi-rendah kontrol diri. Penelitian ini bertujuan untuk mengetahui hubungan antara kontrol diri dengan perilaku merokok kalangan remaja. Metode penelitian menggunakan desain Cross Sectional dan bersifat analitik kuantitatif. Penelitian ini melibatkan 176 siswa aktif sekolah sebagai sampel, merokok dan tidak merokok, berjenis kelamin laki-laki atau perempuan, dan bersedia berpartisipasi. Pengambilan data melalui kuesioner. Teknik analisa data menggunakan uji korelasi Spearman Rank. Hasil penelitian menunjukan nilai $r=-0,756$ dengan $p=0,000(p<0,05)$, artinya semakin tinggi kontrol diri remaja, semakin rendah perilaku merokoknya. Analisis terhadap 44 responden perokok dari total sampel 176 , diperoleh nilai $r=-0,766$ dengan nilai $p=0,000(p<0,05)$, artinya semakin rendah kontrol diri remaja, semakin tinggi perilaku merokoknya. Dengan demikian hipotesis H1 diterima yaitu terdapat hubungan negatif yang signifikan antara kontrol diri dengan perilaku merokok.
\end{abstract}

Kata kunci: kontrol diri, perilaku merokok, remaja

Individu yang memiliki mental sehat dapat melakukan pengaturan terhadap dirinya sendiri dan perilakunya secara efektif.
Kemampuan tersebut membuat individu akan lebih mudah diterima untuk lingkungannya. ${ }^{1,2}$ 
Mekanisme yang dapat membantu mengatur dan mengarahkan perilaku adalah kontrol diri. Kontrol diri pada tiap individu tidaklah sama. Menurut Widiana terdapat individu yang memiliki kontrol diri yang tinggi dan individu yang memiliki kontrol diri yang rendah. ${ }^{3}$

Kontrol diri yang rendah membuat individu tidak mampu mengatur dan mengarahkan perilakunya. Hal ini sering dialami oleh remaja. Menurut Rosandi masa remaja ditandai dengan emosi yang cenderung tidak dapat dikontrol. ${ }^{4}$

Tindakan tidak terkontrol yang sering dikaitkan dengan remaja dan menganggap sebagai suatu kesenangan hati salah satunya yaitu perilaku merokok. ${ }^{5}$

Data WHO menyebutkan bahwa terdapat 1,3 milyar perokok di dunia dan sepertiganya berasal dari populasi global yang berusia 15 tahun keatas. Indonesia saat ini menduduki peringkat keempat dunia sebagai bangsa yang jumlah penduduknya paling gemar merokok yaitu sekitar 140 juta orang setiap harinya mengkonsumsi tembakau. ${ }^{6,7}$

Perilaku merokok penduduk 15 tahun ke atas cenderung meningkat dari 34,2 persen tahun 2007 menjadi 36,3 persen tahun 2013. Terhitung sebanyak 64,9 persen laki-laki dan 2,1 persen perempuan masih menghisap rokok pada tahun 2013. Proporsi penduduk umur $\geq 10$ tahun di Sulawesi utara yaitu 24,6 persen perokok setiap hari dan 5,9 perokok kadangkadang. ${ }^{8}$

Penelitian oleh Muhammad Ulhaq dan Retno Komolohadi tentang "Hubungan antara kontrol diri dengan perilaku merokok pada siswa-siswi SMAN 1 Parakan” menjelaskan bahwa terdapat hasil yang signifikan antara kontrol diri dengan perilaku merokok. $^{3}$

Pada penelitian mengenai intensi merokok oleh Wulandari menjelaskan bahwa pengaruh lingkungan, sikap terhadap perilaku, norma subjektif, persepsi terhadap kontrol perilaku, dan afeksi negatif memberikan hubungan yang signifikan terhadap niat untuk merokok. ${ }^{6}$
Kelas X SMK merupakan kelas awal memasuki jenjang sekolah menengah atas, usia rata-rata 16 tahun dan memasuki lingkungan yang berbeda dengan sebelumnya. Hal ini berpotensi menyebabkan masalah-masalah dalam dirinya termasuk masalah kontrol diri yang rendah terhadap perilaku merokok.

Berdasarkan hasil pengamatan di SMKN 1 Bitung, siswa laki-laki maupun perempuan terlihat sering merokok di tempat perkumpulan mereka. Jika siswa memiliki kontrol diri yang tinggi, maka perilaku merokok akan sulit untuk mempengaruhi kepribadiannya. Namun, perilaku merokok akan mudah menjadi gaya hidup jika individu memiliki kontrol diri yang rendah. Masalah yang telah disebutkan di atas perlu diketahui apa yang menyebabkan perubahan keadaan dari remaja yang seharusnya belajar dengan giat di sekolah menjadi remaja yang kenyataannya lebih tertarik untuk merokok. Apakah ada hubungan antara kontrol diri remaja dengan munculnya perilaku merokok pada remaja kelas X di SMKN 1 Bitung?

\section{METODE PENELITIAN}

Berdasarkan penjelasan dalam latar belakang, peneliti mengajukan hipotesis yaitu:

$\mathrm{H} 0$, artinya tidak ada hubungan yang signifikan antara kontrol dengan perilaku merokok remaja kalangan remaja di SMKN 1 Bitung.

H1, artinya ada hubungan yang signifikan antara kontrol dengan perilaku merokok kalangan remaja di SMKN 1 Bitung.

Variabel pada penelitian ini adalah kontrol diri dan perilaku merokok. Kontrol diri merupakan pengendalian emosi serta dorongan-dorongan yang ada dalam diri. ${ }^{13}$ Perilaku merokok merupakan aktivitas yang dilakukan oleh seseorang berupa membakar dan menghisap serta menimbulkan asap yang dapat terhisap oleh orang-orang disekitarnya. ${ }^{7,14,15}$ 
Desain penelitian yang digunakan adalah Cross Sectional dengan pendekatan analitik. Populasi dalam penelitian ini yaitu siswa SMK Negeri 1 Bitung. Subjek yaitu siswa kelas X berjumlah 316 orang dengan kriteria perokok dan bukan perokok, berjenis kelamin laki-laki atau perempuan. Alat pengumpul data yang digunakan adalah kuesioner kontrol diri dan perilaku merokok. Dalam tryout, peneliti hanya menggunakan kuesioner kontrol diri, oleh karena kuesioner perilaku merokok telah digunakan pada penelitian sebelumnya dan dinyatakan valid. Teknik pengambilan sampel menggunakan cara Simple Random Sampling sehingga total responden yang diperoleh yaitu 176 orang, perokok ( $n=44)$, bukan perokok $(n=132)$. Analisis data secara statistik yang digunakan dalam penelitian ini adalah uji korelasi menggunakan rumus Spearman Rank. Proses analisis ini dipercepat dan dipermudah dengan adanya perangkat lunak komputer.

\section{HASIL ANALISIS DATA}

\section{Skala Kontrol Diri}

Pengukuran variabel kontrol diri berdasarkan teori yang dikemukakan oleh Averill tentang aspek utama kontrol diri.

Uji validitas secara statistik memiliki kriteria sebagai berikut : jika $r$ hitung $>r$ tabel, maka dinyatakan valid, jika $r$ hitung < r tabel, maka dinyatakan tidak valid. Berdasarkan perhitungan derajat kebebasan ( $\mathrm{df}=\mathrm{N}-2$ ), diperoleh hasil 34. Hasil tersebut kemudian dijadikan dasar untuk menentukan $\mathrm{r}$ tabel yaitu 0,3291. Ujicoba kuesioner yang berjumlah kepada 36 aitem kepada 36 responden menghasilkan 20 aitem yang valid dan 16 aitem yang tidak valid.

Nilai Alpha Conbrach yang diperoleh yaitu sebesar 0,837, maka aitem-aitem pertanyaan variabel kontrol diri dinyatakan sangat reliabel karena bernilai $>0,80$.

Jumlah item dalam skala ini adalah 20 item dengan 13 item favorable dan 7 item unfavorable. Kueisioner berisi 4 pilihan kategori, yang akan diberi skor:

- $\quad$ Sangat setuju (SS) $=4$
- $\quad$ Setuju $(S)=3$

- Tidak setuju (TS) $=2$

- $\quad$ Sangat tidak setuju (STS) $=1$

Alternatif jawaban pada item favourable, yaitu : SS, S, TS, STS dengan skor 4, 3, 2, 1, sedangkan alternatif jawaban pada item unfavourable, yaitu : SS, S, TS, STS, dengan skor 1, 2, 3, 4.

Dalam mendeskripsikan tingkat kontrol diri yang memiliki rentang skor 14, dibuat interval kriteria dengan cara: Data maksimal $=4 / 4 \times 100 \%=100 \%$ Data minimal $=1 / 4 \times 100 \%=25 \%$ Range $\quad=100 \%-25 \%=75 \%$ Panjang kelas interval $=$ Range: Panjang Kelas $=75: 4=18,75$

Tabel 1. Kategorisasi Tingkat Kontrol Diri

Variabel Kategori $\quad$ Kriteria

Kontol

Diri Tinggi $\quad 62,50 \%<\% \leq$ $81,25 \%$

Rendah $\quad 43,75 \%<\% \leq$

$62,50 \%$

Sangat Rendah $\quad 25,00 \%<\% \leq 43$,

$75 \%$

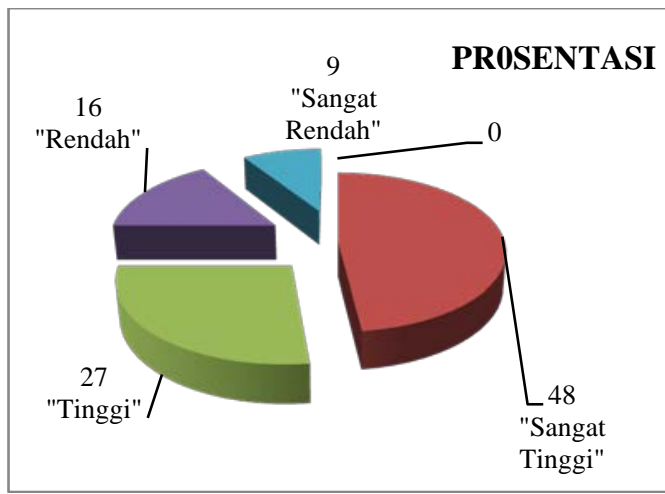

Gambar 1. Kategorisasi Tingkat Kontrol Diri Seluruh Responden 
Gambar di atas menunjukkan tingkat kontrol diri siswa SMKN 1 Bitung kelas X memiliki 4 kategori dengan prosentasi masing-masing yaitu kategori sangat tinggi sebesar 48\% (84 siswa), kategori tinggi sebesar 27\% (48 siswa), kategori rendah sebesar 16\% (28 siswa), dan kategori sangat rendah sebesar 9\% (16 siswa). Berdasarkan prosentasi tertinggi pada hasil analisis deskriptif dapat disimpulkan bahwa tingkat kontrol diri siswa SMKN 1 Bitung kelas X terbanyak berada pada kategori sangat tinggi.

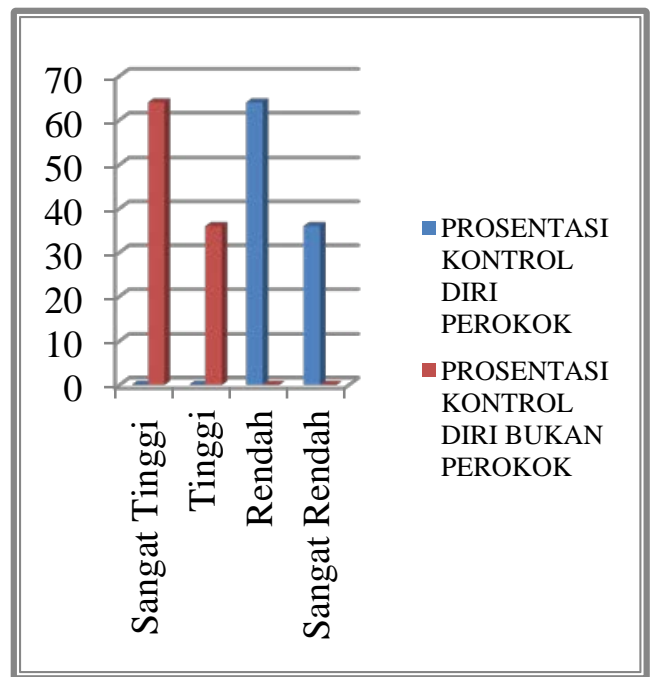

Gambar 2. Kategorisasi Perbandingan Tingkat Kontrol Diri pada Responden yang Merokok dan tidak Merokok

Gambar di atas menunjukkan tingkat kontrol diri berbanding terbalik, antara siswa yang merokok dengan siswa yang tidak merokok di SMKN 1 Bitung kelas X. Pada siswa yang perokok memiliki kontrol diri yang rendah sebesar 64\% sedangkan siswa yang bukan perokok memilikki kontrol diri sangat tinggi yaitu sebesar $64 \%$.

\section{Skala Perilaku Merokok}

Penyusunan pertanyaan kuesioner berdasarkan : tipe perilaku merokok, tipe perokok, tahapan perilaku merokok, faktorfaktor yang mempengaruhi perilaku merokok, dampak perilaku merokok. Responden mengisi kuesioner yang menggunakan skala perilaku merokok dengan pilihan jawaban :

1. Selalu

2. Sering

3. Kadang-kadang

4. Tidak pernah

Pernyataan positif dinilai dengan: selalu (skor 4), sering (skor 3), kadangkadang (skor 2), dan tidak pernah (skor 1). Pernyataan negatif dinilai dengan: selalu (skor 1), sering (skor 2), kadang-kadang (skor 3), dan tidak pernah (skor 4). Jumlah item dalam skala ini adalah 19 butir dengan 11 item favorable dan 8 item unfavorable.

Berdasarkan teori Aritonang pengelompokan perilaku merokok dapat dapat dilihat berdasarkan intensitas (jumlah) rokok yang dihisap perhari. Menurut teori tersebut, perilaku merokok digolongkan kategori rendah apabila merokok antara 1-4 batang per hari, kategori sedang apabila merokok 5-14 batang per hari dan kategori berat merokok lebih dari 15 batang perhari. ${ }^{12}$

Hasil penelitian menunjukan terdapat 44 siswa yang perokok dari total keseluruhan responden. Peneliti menggunakan sampel siswa perokok untuk menentukan perilaku merokok

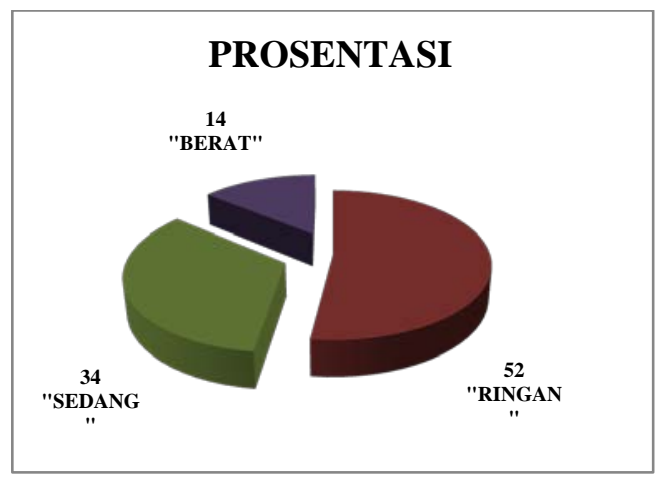

Gambar 3. Kategorisasi Perilaku Merokok pada Responden yang Merokok

Gambar 3 menunjukkan perilaku merokok pada siswa perokok SMKN 1 Bitung kelas $\mathrm{X}$ memiliki 3 kategori dengan prosentasi masing-masing yaitu 52\% untuk kategori perokok ringan (23 orang), 34\% untuk kategori perokok sedang (15 orang), dan 14\% untuk kategori perokok berat (6 
orang). Dengan demikian, perilaku merokok siswa SMKN 1 Bitung kelas X terbanyak berada pada kategori yang ringan.

\section{Hubungan kontrol diri dengan perilaku merokok}

Berdasarkan hasil uji korelasi Spearman Rank diperoleh koefisien korelasi bernilai negatif sebesar $-0,756$ dengan nilai $\mathrm{p}=0,000$. Nilai $\mathrm{r}=-0,756$ menunjukan bahwa terdapat hubungan negatif kuat antara kontrol diri dengan perilaku merokok. Probabilitas koefisien korelasi memenuhi taraf signifikansi 0,05 dimana nilai sig $<\grave{\alpha}=0,000<0,05$, sehingga $\mathrm{H} 1$ dapat diterima sedangkan $\mathrm{H} 0$ ditolak.

Uji korelasi antara kontrol diri dengan perilaku merokok untuk siswa perokok kelas X di SMKN 1 Bitung sebanyak 44 dari total sampel 176 orang, diperoleh koefisien korelasi bernilai negatif sebesar 0,766 dengan nilai $\mathrm{p}=0,000$. Nilai $\mathrm{r}=$ 0,766 menunjukan hubungan negatif yang kuat antara kontrol diri dengan perilaku merokok. Probabilitas koefisien korelasi memenuhi taraf signifikansi 0,05 dimana nilai sig $<\grave{\alpha}=0,000<0,05$.

\section{BAHASAN}

Hasil analisis data statistik menunjukkan bahwa ada hubungan negatif kuat yang signifikan antara kontrol diri dengan perilaku merokok. Berdasarkan data $r=-0,756$ dengan $p=0,000(p<0,05)$, menjelaskan bahwa kontrol diri berhubungan dengan munculnya perilaku merokok siswa kelas X di SMKN 1 Bitung. Angka koefisien korelasi bernilai negatif artinya semakin tinggi kontrol diri maka akan semakin rendah perilaku merokok seseorang, begitu pula sebaliknya, semakin rendah kontrol diri seseorang maka semakin tinggi perilaku merokoknya.

Uji korelasi statistik antara kontrol diri dengan perilaku merokok pada responden perokok di kelas $\mathrm{X}$ di SMKN 1 Bitung sebanyak 44 dari total sampel 176, diperoleh koefisien korelasi bernilai negatif sebesar $-0,766$ dengan nilai $\mathrm{p}=0,000$.
Nilai $r=-0,766$ berarti terdapat hubungan negatif yang kuat antara kontrol diri dengan perilaku merokok. Kesimpulannya sama seperti pada uji korelasi dimana total sampel secara keseluruhan antara kontrol diri dengan perilaku merokok terdapat hubungan negatif yang signifikan.

Teori de Ridder \& de Wit mengemukakan bahwa kontrol diri (selfcontrol) termasuk faktor yang berperan dalam proteksi/perlindungan untuk menjadi pengguna zat-zat berbahaya, termasuk tembakau. ${ }^{9}$

Menurut teori Calhoun dan Accocella ada dua alasan yang mengharuskan individu mengontrol diri terus menerus. Pertama, individu tidak hidup sendirian akan tetapi dalam kelompok dan individu mempunyai kebutuhan untuk memuaskan keinginan dan kebutuhan. Kedua, masyarakat menghargai kemampuan, kebaikan dan hal-hal yang harus diterima lainnya yang dimiliki individu. ${ }^{3}$

Kategorisasi variabel kontrol diri untuk seluruh responden diperoleh terbanyak berada pada kategori sangat tinggi dengan jumlah 84 orang sebesar $48 \%$ dan terendah pada kategori sangat rendah dengan jumlah 16 orang sebesar $9 \%$.

Hasil penelitian oleh Zia Ulhaq dan Retno Komolohadi tentang "Hubungan antara kontrol diri dengan perilaku merokok pada siswa-siswi SMAN 1 Parakan” dengan perincian hasil 1 subjek (0.93 \%) ada pada kategori sangat tinggi, sedangkan pada kategori tinggi sebanyak 61 subjek (56.48 \%). Untuk kategori sedang diperoleh sebanyak 29 subjek (26.85 \%). Kemudian kategori rendah ada 16 subjek (14.8 \%) dan pada kategori sangat rendah ada 1 subjek (0.93\%). Berdasarkan kategori tersebut dapat dilihat bahwa tingkat kontrol diri subjek penelitian terbanyak berada pada kategori tinggi. ${ }^{3}$

Pada responden yang merokok tingkat kontrol diri diperoleh hasil 64\% kategori rendah dengan jumlah 28 orang dan 36\% kategori sangat rendah dengan jumlah 16 orang dari total keseluruhan 44 responden yang merokok. Berdasarkan prosentasi, siswa yang merokok terbanyak berada pada 
kategori kontrol diri rendah, sedangkan pada responden yang tidak merokok tingkat kontrol diri memperoleh hasil 64\% kategori sangat tinggi dengan jumlah 84 orang dan $36 \%$ kategori tinggi dengan jumlah 48 orang dari total keseluruhan 132 responden yang tidak merokok.

Goldfried dan Merbaum mendefinisikan kontrol diri sebagai proses yang menjadikan individu sebagai agen utama dalam memandu, mengarahkan dan mengatur perilaku utamanya yang dapat membawa ke arah konsekuensi positif. Ada individu yang memiliki kontrol diri yang tinggi dan ada yang memiliki kontrol diri yang rendah. Remaja yang memiliki kontrol diri tinggi pada umumnya masih dapat mengontrol dorongan-dorongan yang ada dalam dirinya, sehingga mampu mengendalikan perilaku merokoknya tetap rendah bahkan tidak ada. Begitu pula sebaliknya remaja yang memiliki kontrol diri rendah tidak mampu melepaskan diri dari dorongan - dorongan untuk merokok dan secara terus-menerus terjadi peningkatan jumlah rokok yang dihisap tiap hari, tanpa dapat mempertimbangkan akibat-akibat negatif yang ditimbulkan, baik terhadap dirinya sendiri, ataupun orang - orang di sekitarnya. ${ }^{3}$

Ghufron \& Risnawita mengemukakan bahwa kontrol diri dipengaruhi oleh faktor internal dan eksternal. Faktor internal berhubungan dengan dirinya antara lain usia, jenis kelamin, dan kontrol diri, sedangkan faktor eksternal antara lain lingkungan, baik dalam keluarga, teman sebaya, maupun tempat interaksi sosial. ${ }^{10}$

Teori Aritonang mengelompokan perilaku merokok berdasarkan intensitas (jumlah) rokok yang dihisap perhari. Menurut teori tersebut, perilaku merokok digolongkan kategori rendah apabila merokok antara 1-4 batang per hari, kategori sedang apabila merokok 5-14 batang per hari dan kategori berat merokok lebih dari 15 batang perhari. ${ }^{11}$

Kategorisasi variabel perilaku merokok dari 44 sampel diperoleh hasil responden terbanyak berada pada kategori perilaku merokok ringan dengan jumlah 23 orang sebesar 52\% dan terendah pada kategori perilaku merokok berat dengan jumlah 6 orang sebesar $14 \%$.

Penelitian oleh Zia Ulhaq dan Retno Komolohadi tentang "Hubungan antara kontrol diri dengan perilaku merokok pada siswa-siswi SMAN 1 Parakan” untuk kategorisasi variabel perilaku merokok dari 95 subjek diperoleh hasil 8 subjek (8.4\%) ada pada kategori sangat rendah, sedangkan pada kategori rendah sebanyak 20 subjek (21.1\%). Untuk kategori sedang diperoleh sebanyak 33 subjek (34.7\%). Kemudian kategori tinggi ada 24 subjek (25.3\%) dan pada kategori sangat tinggi ada 10 subjek (10.5\%). Berdasarkan kategori tersebut dapat dilihat bahwa perilaku merokok subjek dalam penelitian tersebut berada pada kategori sedang. ${ }^{3}$ Secara umum menurut Kurt Lewin perilaku merokok merupakan fungsi dari lingkungan dan individu. Artinya, perilaku merokok selain disebabkan faktor-faktor dari dalam diri, juga disebabkan faktor lingkungan. ${ }^{12}$

Penelitian ini menunjukan bahwa kontrol diri sebagai faktor internal memberi pengaruh besar terhadap perilaku merokok. Tinggi rendah kontrol diri seseorang akan memberi respon yang berbeda. Hasil analisis membuktikan terdapat hubungan antara kontrol diri dengan perilaku merokok sehingga $\mathrm{H} 0$ ditolak dan $\mathrm{H} 1$ diterima. Hubungan yang dimaksud bersifat negatif, artinya kontrol diri pada siswa yang kebanyakan berada pada kategori sangat tinggi menyebabkan menurunnya perilaku merokok ataupun dari beberapa siswa dengan kontrol diri rendah justru akan meningkatkan perilaku merokok.

\section{SIMPULAN}

Berdasarkan hasil analisis data secara statistik dengan menggunakan perangkat pengolah data komputer kepada 176 subyek dalam penelitian ini, dengan tujuan menguji hipotesis yang diajukan dalam penelitian ini, maka dapat disimpulkan:

1. Kontrol diri pada siswa kelas $X$ di SMKN 1 Bitung secara keseluruhan responden terbanyak berada dalam kategori sangat tinggi. Pada siswa yang 
perokok terbanyak memiliki kontrol diri yang rendah dibandingkan siswa yang bukan perokok terbanyak memiliki kontrol diri sangat tinggi.

2. Perilaku merokok pada responden yang merokok terbanyak berada pada kategori perilaku merokok ringan.

3. Ada hubungan negatif kuat yang signifikan antara variabel kontrol diri dengan variabel perilaku merokok. Semakin rendah kontrol diri, maka semakin tinggi perilaku merokok pada siswa kelas X di SMKN 1 Bitung

4. Uji korelasi statistik untuk responden yang merokok menghasilkan hubungan negatif yang signifikan antara variabel kontrol diri dengan variabel perilaku merokok pada siswa kelas $\mathrm{X}$ yang merokok di SMKN 1 Bitung.

\section{SARAN}

\section{Sekolah}

Pimpinan sekolah agar dapat membimbing siswa untuk mengurangi perilaku merokok siswa dengan cara melibatkan siswa pada kegiatan positif seperti, olah raga, pramuka, debat antar siswa, lomba kreatifitas siswa dan kegiatan positif lainnya.

\section{Pemerintah}

Pemerintah sebaiknya mengadakan seminar atau penyuluhan mengenai budaya merokok, terutama pada remaja.

\section{Siswa}

Bagi siswa yang tidak merokok, sebaiknya belajar untuk meningkatkan selfcontrol agar tidak terpengaruh oleh teman. Bagi siswa yang baru mulai merokok dan yang telah menjadi seorang perokok, sebaiknya mempertimbangkan kembali dengan mengingat banyaknya efek negatif merokok bagi kesehatan.

\section{Orang tua}

Orang tua diharapkan dapat memberikan perhatian lebih pada anak yang merokok dalam pergaulan agar tetap memiliki teman dan tidak merasa kesepian dengan cara pola asuh yang benar.
Publik

Publik sebagai salah satu pendorong remaja dalam meningkatkan kontrol diri terutama dalam mengatasi perilaku merokok. Masyarakat sekitar sekolah yang melihat siswa merokok agar bertindak untuk menasehati, melarang, dan menghentikan penjualan rokok.

\section{Peneliti selanjutnya}

Bagi peneliti selanjutnya yang tertarik pada bahasan yang sama, disarankan untuk menggunakan variabel - variabel seperti faktor sosial, pola asuh, kognitif, conditioning, atau dapat melanjutkan penelitian ini dengan tujuan lain seperti : untuk melihat aspek-aspek mana dalam indikator perilaku merokok atau kontrol diri yang tinggi dan rendah. Selain itu, dalam pengambilan data dan pembagian kuesioner pada responden agar supaya memberikan sosialisasi atau pengarahan lebih baik lagi untuk menghindari kurangnya sampel yang akan didapat.

\section{DAFTAR PUSTAKA}

1. Sandha $T$, Hartati $S$, Fauziah $N$. Hubungan antara self esteem dengan penyesuaian diri pada siswa tahun pertama SMA Krista Mitra Semarang. Jurnal Psikologi [serial on the internet] 2012 [cited 2014 Nov 3];01(01):4950. Available from : http://ejournals1.undip.ac.id/index.php /empati/article/view/420.

2. Zakiyah N, Hidayati FNR, Setyawan I. Hubungan antara penyesuaian diri dengan prokrastinasi akademik siswa sekolah berasrama SMPN 3 Peterongan Jombang. Jurnal Psikologi Undip [serial on the internet]. 2010 [cited 2014 Nov 3];08(02):160-1. Available from: http://ejournal.undip.ac.id/index.php/p sikologi/article/view/2960/2646.

3. Ulhaq MZ, Komolohadi RAR. Hubungan antara kontrol diri dengan perilaku merokok pada siswa siswi SMAN 1 Parakan. 2008 [cited 2014 Oct 22]. Available from:http://psychology.uii.ac.id/image s/stories/jadwal_kuliah/naskahpublika si-00320158.pdf 
4. Angelina DY, Matulessy A. Pola Asuh Otoriter Kontrol Diri Dan Perilaku Seks Bebas Remaja SMK. Persona Jurnal Psikologi Indonesia [serial on the internet]. 2013 [cited 2014 Oct 22]; 02(02):174. Available from: http://download.portalgaruda.org/articl e.php?article $=253798 \&$ val $=6847 \&$ title $=$ Pola $\% 20$ Asuh $\% 20$ Otoriter $\% 20$ Kont rol\%20Diri\%20\%20Dan\%20Perilaku \%20Seks\%20Bebas\%20Remaja\%20S MK.

5. Maretawati ED, Makmuroch, Agustin RW. Hubungan antara pola pengasuhan dan pola kelekatan dengan penyesuaian sosial pada remaja siswa kelas XI SMA N 1 Sragen. 2010 [cited 2014 Nov 3] :46. Available from: https://www.google.com/url?sa=t\&rct $=\mathrm{j} \& \mathrm{q}=\&$ \&esrc $=\mathrm{s} \&$ source $=$ web $\& \mathrm{~cd}=1 \&$ cad $=$ rja \&uact $=8 \&$ ved $=0$ CB0QFjAA $\&$ url=http\%3A\%2F\%2Fjurnalwacana.ps ikologi.fk.uns.ac.id\%2Findex.php\%2F wacana\%2Farticle\%2Fview\%2F63\%2 F63\&ei=ChLLVLfiJs7W8gWG94LY DQ\&usg=AFQjCNEnRHicFlGOnZB6 698E5Z3WN2njHg\&sig2=uCzimXb7 smuDIM9EDFzKQg\&bvm=bv.84607 526,d.dGc.

6. Melinda E. Hubungan penerimaan diri dan konformitas terhadap intensi merokok pada remaja di SMK Istiqomah Muhammadiyah. E-jurnal Psikologi [serial on the internet]. 2013 [cited 2014 Oct 14];01(01):10. Available from: http://ejournal.psikologi.fisipunmul.ac. id/site/wpcontent/uploads/2013/03/Jur nal\%20Skripsii\%20(03-11-13-05-5450).pdf.

7. Sanjiwani NLPY, Budisetyani IGAPW. Pola asuh permisif ibu dan perilaku merokok pada remaja laki-laki di SMA Negeri 1 Semarapura. Jurnal Psikologi Udayana [serial on the internet]. 2014 [cited 2014 Oct 14];01(02):345. Available from: http://ojs.unud.ac.id/index.php/psikolo gi/article/view/8548.

8. Pratiwi NL, Pradono J, Kusumawardhani N, Tarigan IU. Pengetahuan sikap dan perilaku. Riset Kesehatan Dasar [serial online]. 2013 [cited 2014 Oct 14]:169-175. Available from:http://www.litbang.depkes.go.id/ sites/download/rkd2013/Laporan_Risk esdas2013.PDF .

9. Ramdhani M. Penerapan teknik kontrol diri untuk mengurangi konsumsi rokok pada kategori perokok ringan. Jurnal Sains dan Praktik Psikologi [serial on the internet]. 2013 [cited 2014 Oct 22]; 01(03):242. Available from :http://ejournal.umm.ac.id/index.php/js pp/article/viewFile/1693/1791.

10. Shohibullana IH. Kontrol diri dan perilaku konsumtif pada siswa SMA ditinjau dari lokasi sekolah. Jurnal Online Psikologi [serial on the internet]. 2014 [cited 2014 Oct 22]; 02(01):49-50. Available from : http://ejournal.umm.ac.id/index.php/jo p/article/view/1818.

11. Saputra A. Hubungan antara Harga Diri dengan Perilaku Merokok pada Siswa Laki-Laki SMP di Kota Bukittinggi. Jurnal Psikologi [serial on the internet]. 2013 cited 2015 Januari 20];01(01):7. Available from : http://ejournal.unp.ac.id/students/inde x.php/psi/article/view/594/353

12. Komasari D, Helmi AF. Faktor-Faktor Penyebab Perilaku Merokok pada Remaja. Jurnal Psikologi [serial on the internet]. 2000 [cited 2015 Januari 20];01:38. Available from :http://avin.staff.ugm.ac.id/data/jurnal/ perilakumerokok_avin.pdf

13. Amiril AR. Hubungan antara kematangan emosi dan kontrol diri dengan stress kerja pada guru SLB di Kota Malang. Artikel Penelitian [serial on the internet]. 2013 [cited 2014 Oct 22]:3. Available from

http://jurnalonline.um.ac.id/data/artike 1/artikel17ACC6CDFE4534E60897A9 A3BEF06C0B.pdf.

14. Lestari R, Purwandari E. Perilaku merokok pada remaja SMA/SMK di kota dan luar kota. Prosiding Temu Ilmiah nasional VIII IPPI; 8-10 November 2012; ISBN; c2012. [cited 2014 Oct 14]. Available from : http://psikologi.ums.ac.id/wpcontent/u ploads/2013/09/Perilaku-MerokokPadaRemaja-SMA-SMK-di-Kota danLuar Kota.pdf. 
Jurnal e-Biomedik (eBm), Volume 3, Nomor 1, Januari-April 2015

15. Chotidjah S. Pengetahuan tentang rokok, pusat kendali kesehatan eksternal dan perilaku merokok. Makara Sosial Humaniora [serial on the internet]. 2012 [cited 2014 Oct 14]; 16(01):51. Available from:http://journal.ui.ac.id/index.php/ humanities/article/viewFile/1493/1294 